\title{
O ESTÍMULO DOS SENTIDOS ATRAVÉS DAS IMAGENS: estudo de caso
}

\author{
The stimulation of the directions through the \\ images: a case study
}

Djalma Patrício ${ }^{1}$

Raphael Fontana Günther ${ }^{2}$

\section{Resumo}

Uma campanha de uma marca de perfume nacional trabalha com dois elementos: de um lado, a cidade (urbanismo, agitação e a arquitetura) e, do outro, a natureza (a mata, a água e o verde), exibindo uma clara distinção entre os dois ambientes. Por meio de imagens, busca-se situar o público-alvo nos ambientes distintos (cidade e natureza), sugerindo que um necessita do outro em igual proporção para viver em harmonia. A idéia não denota que um seja ruim e o outro bom, mas sim que a vida precisa ter um ponto de equilíbrio. A correria da vida moderna na cidade precisa ser balanceada com um maior contato com a natureza. Os anúncios impressos da campanha trabalham com a associação das palavras "Expire" ao urbano e "Inspire" à natureza, finalizando com uma imagem do perfume Arbo associado à palavra "Inspire". Busca-se compreender o estímulo dos Sentidos por meio das imagens, em uma análise dos elementos de semiótica empregados nos anúncios da campanha publicitária "Expire e Inspire".

Palavras-chave: Publicidade; Sentidos; Campanha; Estímulo; Semiótica.

\section{Abstract}

The campaign of a fragrance works with two elements: the city (urbanism, agitation and the architecture), and the nature (woods, the water and the green), showing a clear distinction between two environments. Through images, one searches to point out the public-target in two distinct environments (city and nature), suggesting that one needs the other in equal ratio to exist in harmony. The idea does not denote that one is bad and the other is good, but that the necessary life to have a break-even point. The running of the modern life in the city needs to be balanced with a bigger contact with the nature. The announcements printed matters of the campaign work with the association of the words "Exhale" to the urban one and "Inhale" to the nature, finishing with an image of the Arbo perfume associated with the word "Inhale". One searches to understand the stimulation of the Directions through the images, in an analysis of the elements of semiotics used in the announcements of the advertising campaign.

Keywords: Publicity; Senses; Campaign; Stimulus; Semiotics.

1 Professor e jornalista, Doutor em Letras, com tese em História e Crítica do Cinema na Universita degli Studi di Roma - Itália. djalma@furb.br

2 Graduando em Comunicação Social com Habilitação em Publicidade e Propaganda da FURB - Universidade Regional de Blumenau-SC. 


\section{Introdução}

Anos atrás, uma campanha de um perfume $^{3}$ trabalhou com dois elementos principais: a cidade (urbanismo, agitação e arquitetura), e a natureza (a mata, a água e o verde), lado a lado, exibindo uma clara distinção entre os dois ambientes. Por meio de imagens, busca-se situar o público-alvo em distintos ambientes (cidade e natureza). Este trabalho procurou analisar e entender o porquê de termos a percepção do aroma de um perfume por meio de uma imagem, sem que se tenha estado em contato direto com ele pelo olfato, procurando esclarecer as razões para que uma peça, que faz uso de imagens, consiga estimular a compra de um perfume. A fragrância aromática tem ligação direta com o olfato, e não com o sentido da visão, como as imagens. Foi feita também uma análise das cores empregadas nas peças e descobrir qual carga de responsabilidade elas têm na assimilação da mensagem da campanha mediante a associação delas com os ambientes exibidos nas fotografias; e as possibilidades de transmissão de sensações não peculiares de imagens estáticas por meio de um anúncio impresso (estático), como o som e o movimento.

A leitura dos elementos visuais foi concentrada nas peças impressas, veiculadas em revistas e outdoors. Essa campanha teve peças para TV, que também incluíam trilha sonora e movimento, agregando dessa forma outras sensações à exibição das imagens que merecem outra pesquisa específica e minimizam questões pertinentes a esta.

Supõe-se que a utilização de símbolos e signos nas imagens estimula, por meio da visão, os outros sentidos do ser humano: audição, tato, olfato, paladar e, possivelmente, o equilíbrio (um sexto sentido diferente do que se popularizou como tal), em conseqüência do histórico cultural de cada pessoa.

O mercado publicitário vive um momento de grandes e numerosas inovações tecnológicas. Com a evolução da informática e o advento da Internet, descobriram-se novos rumos e novas mídias para a criação e veiculação publicitária. Conseqüentemente, houve também uma renovação nos veículos mais antigos, à custa, principalmente, da busca de novas possibilidades e saídas criativas para problemas de identificação entre produtos, serviços e consumidores. A campanha "Expire e Inspire" é, dentro deste contexto, moderna e venceu alguns prêmios, o que merece um estudo analítico sobre suas características.

\section{Revisão de literatura}

Para esta análise, foi preciso fragmentar os elementos visuais das peças gráficas da campanha "Expire e Inspire" e entender a interação desses elementos dentro da criação publicitária a partir de teorias básicas da comunicação social e mercadológica. Para tal, fez-se necessária uma contextualização dessas teorias, utilizadas como bases para este estudo. Serão analisados principalmente: Publicidade \& Propaganda e a mídia; Sentidos; Semiótica; Cor; Fenomenologia.

\section{Publicidade, propaganda e a mídia}

Apesar de ser um fenômeno recente, a propaganda existe desde tempos remotos. Para Martins (2004), a propaganda nasceu quando alguém disse a outro que tinha alguma coisa a oferecer, um produto ou um serviço. Ele também conta que o nome propaganda só viria a ser difundida a partir da Congregatio Propaganda Fide, ou Congregação para a Propagação da Fé, organismo que o Vaticano criou no início do século XVII. A origem da palavra, em latim, significava propagação, mas com o sentido de semear, aguardando a colheita, sendo este o primeiro salto histórico de eficiência e tendo dividido a evolução da palavra e sua eficiência prática. O segundo momento teria sido com Joseph Goebbels, ministro das comunicações do $3^{\circ}$ Reich e principal responsável pelo sucesso de Adolf Hitler. Um terceiro seria do constante desenvolvimento dos meios de comunicação, particularmente os eletrônicos, a partir do final da década de 1950 que, ainda segundo Martins (2004, p. 25), "vem possibilitando o surgimento quase diário de novas técnicas e manifestações estéticas no mundo da Propaganda."

\footnotetext{
${ }^{3}$ O Boticário lançou a fragrância Arbo com a campanha "Expire e Inspire".
} 
Sampaio (2003, p. 26) define a Propaganda como "a manipulação planejada da comunicação, visando, pela persuasão, promover comportamentos em benefício do anunciante que a utiliza." Para ele, geralmente cabe à propaganda informar e despertar nos consumidores o interesse por um produto ou serviço, em benefício de um anunciante (empresa, pessoa ou entidade que se utiliza da propaganda)

A idéia principal sobre a palavra varia de autor para autor, alguns diferenciando Publicidade de Propaganda, outros não. Para Veronezzi (2002, p. 21-22), "Propaganda tem o sentido de propagar princípios, idéias, conhecimentos", enquanto a Publicidade engloba a ação profissional, "a arte de exercer uma ação psicológica sobre o público, com fins comerciais ou políticos, em geral, através de anúncios." Refere-se essencialmente à atividade profissional relacionada à confecção da propaganda.

Para Sampaio (2003), a função principal da propaganda e da publicidade é disseminar informações, raciocínios e idéias que permitam aos consumidores estarem mais informados sobre os produtos e serviços existentes e à sua disposição, possibilitando aos anunciantes o aumento de seus negócios, com a conquista de mais consumidores. O autor cita que no mundo desenvolveu-se uma vasta tecnologia sobre propaganda, fazendo uso de diversos ramos do conhecimento humano (artes plásticas, música, sociologia, psicologia, etc.), para criação e produção da propaganda eficaz.

De acordo com Sampaio (2003, p. 27), "nenhum consumidor é obrigado a absorver a propaganda que lhe é dirigida", e "um dos requisitos mais importantes para que a mensagem publicitária seja bem recebida [...] é que seja atraente e interessante.” Já Veronezzi (2002, p. 131) explica que, em razão das condições técnicas e tecnológicas que propiciam aos meios transferir ao público (que é o receptor) cada vez mais poder para decidir quando, o que, quanto e onde, ele quer ver, ouvir, ler ou arquivar as informações que lhe interessam, sejam elas culturais ou de entretenimento.

Entre o anunciante e o consumidor existe o veículo de comunicação - o meio que torna a mensagem do anunciante acessível ao consumidor, à mídia. Este pode ser um cartaz, um jornal, a televisão, o rádio, etc. Cada veículo tem características peculiares que podem ser interessantes ou não para o resultado esperado em uma propaganda perante o desejo do anunciante. Tais características são definidas a partir da criação da peça ou campanha e associados aos veículos pelo profissional de Mídia.

A revista é um veículo que estabelece maior identificação cultural com o leitor, já que as pessoas só compram revistas que tratam de assuntos de seu interesse específico. Os anúncios em revistas oferecem o benefício do direcionamento preciso para muitos segmentos de consumidores, segundo Sampaio (2003, p. 100), com "o clima adequado para tratar de assuntos específicos, da possibilidade do uso da cor, do espaço para abordagens mais detalhadas e, pelo modo como se consomem as revistas, de diversos impactos para cada anúncio publicado."

Os veículos existentes são muitos e segmentados: televisão, rádio, jornais, cartazes, panfletos, internet, etc. Cada um possui características próprias que devem ser exploradas adequadamente pela equipe de criação juntamente com o profissional de Mídia, otimizando a propaganda perante o público-alvo, com sua base em uma comunicação dirigida de linguagem compatível e, conseqüentemente, eficiente.

\section{Os sentidos}

Os sentidos são os canais pelo qual o homem e os demais animais absorvem informações do mundo exterior, segundo Ninio (1991, p. 19-20):

O que sabemos do mundo exterior é extraído de informações que nos chegam filtradas pelos órgãos dos sentidos, processadas por processos neuronais desenvolvidos ao longo da evolução para satisfazer as exigências da vida animal.

Os sentidos servem às diferentes formas de percepção. Informam-nos sobre o mundo exterior (informações objetivas), e sobre as condições do nosso próprio corpo (informações subjetivas). Uma sensação nada mais é do que a percepção de uma alteração no estado do próprio aparelho nervoso dos sentidos.

São cinco as formas pelas quais o ser humano pode receber estímulos do mundo exterior: visão, olfato, paladar, audição e tato. Cada sensação é decodificada por um órgão ou conjunto 
de órgãos. De maneira simplificada: visão pelos olhos, tato pela pele, audição pelos ouvidos, paladar pela língua e olfato pelo nariz. As informações são então emitidas ao cérebro, gerando uma reação ao julgamento do receptor. Todos os sentidos se encontram organizados segundo o mesmo princípio: as células dos sentidos estão ligadas a filamentos nervosos que conduzem ao interior do organismo. Basicamente, estes nada mais são do que o início das fibras nervosas que transmitem as impressões ao cérebro, que ordena e avalia a informação recebida.

Tem-se falado muito em um sexto sentido denominado equilíbrio. Este não era levado em conta nas publicações até relativamente recente. Ninio (1991, p. 34) cita: "Aos cinco sentidos, paladar, olfato, audição, tato e visão, deveríamos acrescentar outros, igualmente vitais, mas cujos órgãos se encontram bem dissimulados: o sentido da verticalidade, do campo magnético, da temperatura, da pressão...".

Vê-se com o exemplo que o Equilíbrio não era considerado um sentido de fato, mas um desses supostos sentidos dissimulados em outros órgãos. Sentido decodificado por uma pequena estrutura chamada de aparelho vestibular, dentro do aparelho auditivo, o Equilíbrio não tem a ver com a audição. Tratase da percepção espacial da direção. É essa estrutura quem informa o cérebro para onde estamos indo. Alguns o consideravam parte do tato. Para outros, teria relação com a intuição ou alguma forma de premonição mediúnica.

Junto ao ouvido humano existe uma estrutura chamada de aparelho vestibular, que não é responsável pela audição, mas pelo equilíbrio. (...) Quando a gente se mexe muito, em qualquer direção que seja, é nessa região que os movimentos são detectados. Por dentro, essa estrutura é cheia de líquidos e com células que parecem fiozinhos de cabelo. Se a gente derrapa para um lado, as células fininhas vão para o mesmo lado. São elas que dizem para o cérebro em que direção está indo. Assim funciona o sentido do equilíbrio. (FANTÁSTICO, Rede Globo, 2005)

A aprovação ou não de um determinado estímulo dos sentidos varia de pessoa para pessoa. Não há uma certeza predeterminada para a preferência de cada um por uma ou outra variação nos estímulos sensoriais, mas sabe-se que o perfil psicológico de cada pessoa, sua bagagem cultural, seu sexo, sua idade e inclusive sua etnia são fatores a serem considerados nessa análise. Mesmo que não se prove com exatidão o que define essas preferências. (POUND apud GUIMARÃES, 2004, p. 25).

Dentro do universo da Publicidade, buscase constantemente o melhor caminho para que a mensagem chegue eficientemente ao público-alvo. É constante o interesse em saber do consumidor quais são suas motivações, seus gostos e seus objetivos, estando assim ciente das reais possibilidades existentes para a criação de uma campanha publicitária. O impacto de uma mensagem publicitária está no seu poder de mexer emocionalmente com o público-alvo, estimulandoo a ter uma reação que objetive a compra ou uso de um determinado produto ou serviço. O canal para se chegar a essa reação é a combinação dos sentidos. (PÉNINOU et al., 1973, p. 63).

Cada tipo de veículo de comunicação se faz valer de um artifício próprio e dependente de um ou mais sentidos para que tenha sua mensagem assimilada. O Rádio, por exemplo, baseia-se na audição. É um meio de comunicação que não traz estímulo explícito à visão, ou ao tato. A TV, outro exemplo, estimula a visão e a audição. Já uma Revista impressa faz uso da visão e do tato. Como conseqüência da evolução dos trabalhos e avanço da Publicidade \& Propaganda como ciência (se é que esta pode ser assim chamada), tem-se buscado uma maior abrangência nos estímulos. Nestes exemplos comparativos, a TV traz, além do som, a imagem, estimulando os sentidos da visão e da audição, sendo muito mais popular, tornando-se, com o passar dos anos, o meio de comunicação de massa mais procurado para a veiculação de campanhas publicitárias.

Uma explicação para o sucesso da Televisão seria a quase que virtuosa variedade de estímulos que ela proporciona ao espectador, sem exigir muito deste. Um deficiente visual pode ouvir a televisão, assim como um deficiente auditivo poderia assisti-la, características não peculiares ao Rádio, que não poderia ser ouvido, e a uma Revista, que não poderia ser lida. Porém, têm-se buscado novas possibilidades criativas para situações como esta. Não somente para que um deficiente possa também receber a mensagem, mas sim para que 
ocorram mais estímulos e, conseqüentemente, maior chance de que a mensagem possa ser assimilada e a reação, que levaria ao consumo, atingida.

Os anúncios feitos para a mídia impressa estão cada vez mais criativos e arrojados. Se, há algum tempo, a informação se resumia ao estímulo visual, à imagem, hoje em dia, com técnicas criativas ligadas a texto, cores e formas, exploram-se novos campos, que buscam também a interação dos sentidos. A imagem continua sendo considerada o estímulo mais impactante e essas novas técnicas exploratórias são mais notáveis quando a imagem não está presente. Segundo Péninou et al., (1973, p. 63), "uma publicidade sem imagem hoje não é mais representativa do gênero, como o foi numa certa época".

Campanhas publicitárias de perfumes freqüentemente têm feito uso de apliques com o aroma da fragrância no papel das peças gráficas, agregando assim o estímulo olfativo do cheiro ao estímulo visual da imagem. A exemplo da leitura em Braile, para cegos, que é feita pelo tato, com marcações em relevo em vez de letras impressas, o uso de apliques que causem diferentes sensações ao toque também têm sido feito em larga escala, como o uso de papel camurça na impressão da figura de um cachorro. Subitamente, agrega-se à visão o tato. Assim, aumenta a probabilidade de que a informação seja assimilada e o ato da compra efetivado.

\section{Semiótica}

Comunicamo-nos e nos orientamos por meio de imagens, gráficos, sinais, números, sons, gestos, expressões, cheiro, tato, do olhar, do sentir e do apalpar. De todas as aparências sensíveis, o homem, em sua eterna busca para saber os porquês, desvenda significações. O Signo é um sinal ou símbolo que carrega consigo alguma informação.

A Semiótica é o estudo dos signos. Ela engloba toda a fundamentação da linguagem, da comunicação e da transmissão de mensagens, por intermédio de símbolos visuais. O nome Semiótica vem da raiz grega semeion, que quer dizer signo. Santaella (1990, p. 13) diz que:
A semiótica é a ciência que tem por objeto de investigação todas as linguagens possíveis, ou seja, que tem por objetivo o exame dos modos de constituição de todo e qualquer fenômeno como fenômeno de produção de significação e de sentido.

Tais fenômenos sempre estiveram presentes na história da humanidade. O homem das cavernas tentava comunicar-se por desenhos rudimentares que fazia nos locais onde habitava. Os egípcios da antiguidade faziam amplo uso de desenhos simbólicos e até mesmo as nações contemporâneas, como os japoneses e chineses, possuem uma linguagem escrita baseada em símbolos, e não em letras únicas, como os ocidentais, que, diga-se, também não deixam de ser símbolos.

Um dos precursores da Semiótica foi Charles Sanders Peirce, filósofo americano que se tornou conhecido por seus estudos na área da Lógica, tendo enorme contribuição para o desenvolvimento de pensamentos a respeito de Semiótica.

Para ele, o signo envolve uma tripla relação entre objeto e interpretante. "Um Signo é algo que representa alguma coisa para alguém." (PEIRCE, 1977, p. 46).

A designação Signo era usada por Peirce para denotar um objeto perceptível ou apenas imaginável, que represente alguma outra coisa - o Objeto, e seja diferente do seu próprio Signo. Peirce (1977) dizia que por meio da observação dos caracteres dos Signos, em uma leitura abstrata que é peculiar a cada um, somos levados a afirmações sobre os Objetos. E daí surge o interpretante.

Vários outros autores seguiram a busca de Peirce numa forma de compreender a linguagem visual, como fez Santaella (1990, p. 58-59). Umberto Eco (1980, p. 58) dizia que "Um signo é tudo que leva outra coisa a referir-se a um objeto a que ele próprio se refere."

O filósofo Roland Barthes refletiu bem o uso intencional e criativo de elementos de Semiótica para a comunicação dirigida. Segundo Barthes (1979, p. 44), "O signo semiológico também é, como seu modelo, composto de um significante e um significado." Ele citava a cor de um semáforo como uma ordem no trânsito e conceituava que "muitos sistemas semiológicos (objetos, gestos, imagens) têm uma substância de a expressão cujo ser não está na significação: são, muitas vezes, 
objetos de uso, derivados pela sociedade para fins de significação." Seu pensamento surgiu como luz para o estudo publicitário ao afirmar que "a roupa serve para nossa proteção, a comida para nossa alimentação, ainda quando, na verdade, sirvam também para significar."

Resumidamente, Barthes (1979) dizia que o significado de um signo só pode ser entendido como sendo "algo" que quem emprega o signo entende por ele. Se não se localiza com precisão o Signo, facilmente se chega bastante perto de seu caráter. Tal designação é efetiva e amplamente explorada, criativamente, no universo da Publicidade. A aplicação intencional de um símbolo geométrico, cor ou desenho a um determinado contexto, por exemplo, possibilitará ao objeto a denominação de signo. Este objeto, agora signo, ainda terá interpretações diferentes se usado em outro contexto.

Eco (1980, p. 25) dizia que toda a Comunicação com passagens de estímulos e sinais resulta em causas e efeitos: "A teoria da informação nos diz que ali ocorreu um processo informacional, considerado por muitos comunicativo."

Dentro da Publicidade, o contexto de um signo pode ser direcionado de maneira simples, com o agregado do texto. E este também é um signo. De maneira até certo ponto incoerente, ao mesmo tempo muito mais completo e incompleto do que uma imagem, como uma fotografia. Um quadrado, preenchido da cor vermelha com a palavra "sangue" escrita em seu centro, agrega valor à mensagem de tal maneira que talvez com a ausência desta palavra nem fosse possível a transmissão adequada da mensagem. A cor, por sua vez, agregaria enorme valor à palavra "sangue" caso o procedimento fosse o inverso.

Peirce, Eco, Barthes e outros aprofundaram suas teorias sobre os Signos, estabelecendo regras, classificações e explicações para a interpretação de cada fator pertinente à transmissão de uma mensagem por meio de códigos da comunicação. Apesar de relevante, não temos espaço para dar um maior aprofundamento sobre o assunto, explorado amplamente por vários autores, entre os quais os citados acima.

\section{Acor}

No contexto em que se faz este estudo, buscamos nas relações cromáticas os seus valores criativos para uma campanha publicitária e a ciência da Comunicação Social de forma geral. Guimarães (2004, p. 12) refere-se à cor como sendo "uma informação visual, causada por um estímulo físico, percebido pelos olhos e decodificada pelo cérebro."

A cor é um aspecto físico da natureza. Sua explicação científica é de que cada objeto tem sua cor determinada pelos comprimentos de onda dos raios luminosos que as suas moléculas constituintes refletem, e um objeto terá determinada cor se não absorver justamente os raios correspondentes à freqüência daquela cor.

Dentre os vários elementos pertinentes à linguagem visual, a cor talvez seja o que merece mais atenção neste estudo. É notória sua importância dentro de uma análise semiótica, por agregar valores importantes à percepção visual dos signos, muitas vezes alterando o próprio significado deles. E ainda mais quando esses significados são previamente pensados, em caráter criativo, para uma publicidade. O conhecimento das cores tem sido uma ferramenta de grande valor para Designers, Arquitetos, Fotógrafos, Artistas Plásticos e Publicitários, entre outros profissionais que se utilizam das imagens e grafismos para a comunicação e exposição de suas idéias, como descreve Guimarães (2004):

A cor, unida em todas as suas dimensões, torna-se um instrumento útil para jornalistas, designers, artistas e comunicadores em geral que buscam compreender e fazer da cor mais um importante suporte de informação.

Séculos atrás, a cor era observada de maneira romântica, enquanto ainda desconhecidas, em sua totalidade, as suas características físicas. O filósofo Platão (apud GUIMARÃES, 2004) escreveu que a Cor é a sensação formada pela união entre as chamas emanadas pelos corpos e o fogo da vista.

Artistas que viriam a ser referência, como Wassily Kandinsky, já percebiam na cor uma ferramenta importante e de grande valor para suas obras, em virtude de sua percepção única pelo homem. Kandinsky (1991) apud Guimarães (2004) dizia que "a cor provoca, portanto, uma vibração psíquica. E seu efeito físico superficial é apenas, em suma, o caminho que the serve para atingir a alma". Da mesma maneira, Leonardo da Vinci (apud GUIMARÃES, 2004) poetizava as cores como a principal via para que o sentido comum possa 
simples e magnificamente julgar as infinitas obras da natureza.

A cor também é, a exemplo da arte, parte fundamental da mensagem publicitária, sendo explorada como uma técnica de criação muito válida graças ao seu potencial em causar estímulos visuais e carregar informações sígnicas. A informação cromática contida em um produto de comunicação deve ser recebida como a correspondência entre o conteúdo produzido e a mensagem. A identificação dos códigos de comunicação e de suas influências faz parte do processo de conhecimento e produção consciente.

A relação entre a Cor e a Semiótica se dá quando a cor, em utilização conjunta com um objeto, agrega valor simbólico a este. A cor por si só não pode ser considerada um signo, mas quando aplicada intencionalmente em algum objeto, adquire este valor. A cor se torna uma informação, uma codificação cultural. A aplicação intencional da cor também possibilitará ao objeto receber a denominação de signo.

As cores, dentro da sociedade, assumem papéis de manifestações culturais. No Brasil, vivenciamos freqüentemente situações que servem de exemplo a esta afirmação. Por exemplo: referese ao time de futebol do Cruzeiro, de Minas Gerais, como "Azulão", em virtude de seu uniforme azul. Da mesma maneira, o time do Palmeiras, de São Paulo, é conhecido popularmente como "Verdão". Tais situações, exemplo nestes casos, são largamente exploradas pelos jornais noticiosos, por serem formas simples, rápidas e diretas de que a mensagem atinja o leitor. Portanto, a aplicação de uma ou outra cor em uma peça publicitária pode ser influenciada por diversos fatores - entre os quais a percepção de forma coerente com o contexto em que está sendo aplicada. J. W. Goethe foi um dos grandes escritores a tratar do assunto "Cor". Seus textos trazem muito sobre a relação da humanidade com a cor.

Guimarães (2004, p. 109) atesta a importância dos escritos de Goethe, dizendo que é possível, com a escolha de combinações diferentes e "tomando por base o Triângulo de Goethe, provocar efeitos de lucidez, seriedade, melancolia, serenidade, etc.”. Aqui se nota uma associação evidente da percepção diferenciada dos sentidos (não necessariamente todos, mas sim a visão) pelas cores. O Triângulo de Goethe era baseado nas cores Vermelho, Amarelo e Azul, tido por ele como primárias. Consistia em uma estrutura triangular com os três vértices formados por essas cores, e o restante com triângulos de cores secundárias e terciárias, formadas pela mistura das cores dos outros triângulos. A proposta de Goethe era de desvendar os segredos das cores, segundo Brown apud Norman (2005). Para Goethe (1993), era importante entender a reação humana à cor. Ele acreditava que seu triângulo era um diagrama da mente humana e de como ela associava cada cor a uma emoção. Tal teoria deu início à psicologia moderna das cores, e vem, inevitavelmente, afetar a maneira de se pensar uma criação publicitária que faça uso das cores.

A cor sempre foi um fator presente na evolução cultural do homem. O preto, por exemplo, em muitas sociedades, carrega o medo da morte, o que é uma característica cultural. O branco, em oposição, é a cor da vida e da paz. Por vezes, a informação cromática determina o espaço em que surgirá a informação simbólica. E nesse ponto abre-se espaço para que a cor seja uma importante ferramenta de criação artística, podendo, portanto, ser usada das mais variadas maneiras pelos profissionais da comunicação.

\section{A fenomenologia}

A Fenomenologia como ciência nasceu na segunda metade do século XX, com as análises de Franz Brentano sobre a intencionalidade da consciência humana, que tratava de descrever, compreender e interpretar os fenômenos que se apresentam à percepção. O método fenomenológico se define como uma volta às coisas mesmas, isto é, aos fenômenos, aquilo que aparece à consciência, que se dá como objeto intencional. Seu objetivo é chegar à intuição das essências, isto é, ao conteúdo inteligível e ideal dos fenômenos, captado de forma imediata. Toda consciência é consciência de alguma coisa. Assim sendo, a consciência não é uma substância, mas uma atividade constituída por atos (percepção, imaginação, especulação, volição, paixão, etc.), com os quais visa algo.

As essências ou significações (noema) são objetos visados de certa maneira pelos atos intencionais da consciência (noesis). A fim de que a investigação se ocupe apenas das operações realizadas pela consciência, é necessário que se faça uma redução fenomenológica ou Epoché, isto 
é, coloque-se entre parênteses toda a existência efetiva do mundo exterior.

Na prática da fenomenologia, efetua-se o processo de redução fenomenológica, o qual permite atingir a essência do fenômeno. As coisas, segundo Husserl, caracterizam-se pelo seu inacabamento, pela possibilidade de sempre serem visadas por noesis novas que as enriquecem e as modificam.

Um fenômeno é um evento observável, geralmente notável. Fenômeno tem um significado específico na filosofia de Immanuel Kant, que contrastou o termo 'Fenômeno' com 'Nómeno'. Fenômenos constituem o mundo como nós o experienciamos, em oposição ao mundo como ele existe, independentemente das nossas experiências (things-in-themselves, 'das ding an sich', coisas-emsi). Segundo Kant, os humanos não podem saber coisas-em-si, apenas coisas que experienciam. A filosofia deve, portanto, preocupar-se em compreender o próprio processo da experiência. O conceito de 'Fenómenos' levou a uma tradição filosófica conhecida como Fenomenologia e algumas personalidades se destacaram nesta tradição: Hegel, Husserl, Heidegger e Derrida. A percepção de Kant acerca dos fenômenos foi também interpretada como influenciadora no desenvolvimento de modelos psicodinâmicos da Psicologia, e de teorias acerca do modo como o cerébro e a mente interagem com o mundo exterior (WIKIPEDIA, 2005).

\section{Análise da campanha}

Em 1977, uma empresa brasileira iniciou suas atividades como farmácia de manipulação em Curitiba (Paraná) no ramo de cosméticos e perfumaria. Depois do sucesso de vendas, com uma loja no aeroporto Afonso Pena, da mesma cidade, o Boticário inaugurou uma fábrica, em 1982, em São José dos Pinhais, próximo à capital. Hoje, a empresa conta com $35.000 \mathrm{~m}^{2}$ de área construída e cerca de 1250 funcionários. O Boticário detém o posto de maior franqueadora do setor de perfumaria e cosméticos do Brasil, com cerca de 350 itens diferentes entre as linhas feminina, masculina e infantil.

A campanha publicitária "Expire e Inspire" foi desenvolvida em 2004 pela agência OpusMúltipla, de Curitiba (PR), com criação de
Maurício Groff e Patrícia Papp, para o lançamento da fragrância feminina Arbo, de O Boticário. O produto foi um dos principais lançamentos na área de perfumaria e buscava destacar os valores da empresa, fortalecendo a marca com uma fragrância feminina que traduzia a harmonia com a natureza. Há na campanha uma relação do produto e seu conceito com a Fundação O Boticário de Proteção à Natureza, uma organização sem fins lucrativos, cuja missão é promover e realizar ações de conservação da natureza no Brasil. As fotografias de natureza utilizadas nas peças impressas e as imagens do VT foram feitas na reserva Salto Morato, pertencente à Fundação. Segundo o diretor de criação da agência, Renato Cavalher, (OPUSMÚLTIPLA, 2005), a utilização da Reserva no filme e nas peças gráficas também reforça a preocupação constante de O Boticário com a preservação ambiental e fonte inspiradora para a criação.

A campanha consta de anúncios seqüenciais nas revistas Caras, Nova e Claudia, outdoors e filmes, sendo que este último formato não foi analisado neste trabalho. A escolha dos veículos foi de acordo com o público-alvo feminino. O conceito da criação parte do contraste entre a exuberância da natureza e a agitação da cidade grande. O tema "Arbo, A Essência da Natureza", buscou evidenciar as características do perfume, cujo aroma tenta reproduzir a sensação de estar em contato direto com a natureza. O jogo de títulos "Expire" e "Inspire", presente nas peças gráficas e eletrônicas, buscou reforçar o conceito de que a correria da cidade, no trânsito ou no trabalho, pode ser contrabalançada com um maior contato com a natureza. O produto na loja virtual da empresa é anunciado como "uma fragrância exuberante e feminina que reproduz a sensação de estar em contato com a natureza" (O BOTICÁRIO, 2005). O diretor de criação da agência OpusMúltipla, Renato Cavalher, menciona ainda que não pretendiam, com este conceito, mostrar que o urbano é ruim e a natureza é melhor. A intenção era apenas mostrar que existe um ponto de equilíbrio (OPUSMÚLTIPLA, 2005).

De acordo com as informações repassadas pela própria agência, a partir do briefing estabelecido pelo cliente, a campanha deveria transmitir a alma do produto: natureza, feminilidade, leveza, cheiros e emoções. Tinha como proposição "Arbo. Uma fragrância em 
harmonia com a natureza". O público-alvo da campanha era a mulher urbana, acima de 20 anos, de classe econômica A/B, cujo perfil pressupunha que:

Vivencia várias situações de estresse da vida moderna; Busca de caminhos alternativos para relaxar e desfrutar dos prazeres simples da vida; Curte a família e os amigos e se permite ficar "à toa"; Valoriza o bem-estar; Gosta de viajar, e principalmente de estar em contato com a natureza, mesmo dentro de casa.

Dentre os objetivos de comunicação da empresa, estavam:

Fortalecer a marca; Sobressair à concorrência; Impactar, fazendo o público-alvo ir até a loja para conhecer o produto; Ressaltar a simplicidade, a alegria e a jovialidade do produto e da marca O Boticário por meio de atitudes saudáveis e positivas; Valorizar o contato com a natureza; Inovar a comunicação da empresa.

Os anúncios foram veiculados nas revistas Cláudia, Nova e Caras (títulos com maior público feminino), em peças simples ou página dupla, seqüenciais quádruplos (duas páginas) ou seqüenciais sêxtuplos (três páginas), nos meses de maio e junho de 2004. O outdoor consistia em uma peça única e era fechado diretamente pelos franqueados. O VT (que não foi aqui analisado) veiculou na Rede Globo, entre os dias 16 e 23 de maio de 2004, nos programas de maior audiência: novelas das 18h, 19h e 20h, JN, Fantástico, Globo Repórter, Vídeo Show, Mais Você, Jornal Hoje e Vale a Pena Ver de Novo.

A agência, a pedido do cliente, não quis fornecer o valor do investimento financeiro aplicado. Conforme dados pesquisados (AZEDO, 2004), entre o desenvolvimento do produto e a apresentação, foram gastos cerca de R $\$ 4$ milhões. A campanha "Expire e Inspire" teve alguns prêmios conquistados pela agência, como o bronze no $28^{\circ}$ Colunistas Paraná (28ํ PRÊMIO COLUNISTAS PARANÁ, 2004) e o 1ํo lugar no prêmio Criação Sul 2005, da Editora Abril (PRÊMIO ABRIL DE PUBLICIDADE, 2005).

A campanha, baseada no contraste a partir do jogo das palavras do título "Expire" e "Inspire", onde uma é o antônimo da outra, e da aplicação de imagens relacionadas a estas palavras, busca a idéia de equilíbrio por meio da diagramação - feita com espaços de igual tamanho para cada peça e distribuindo a arte igualmente entre esses espaços. Cada lado deste contraste demonstra ter $50 \%$ da informação. Segue-se com anúncios veiculados de forma seqüencial nas revistas, em um ritmo que ora parece tenso quando da palavra "Expire" e ora parece calmo, com a palavra "Inspire", terminando na sensação de repouso com a imagem do produto, associado à palavra "Inspire". O produto, fotografado em um ângulo reto à nossa visão, eliminando a tridimensionalidade e mantendo um plano "chapado", está estático sobre um fundo claro - reforçando a idéia do repouso e da definição.

"Expire" e "Inspire" são termos com significados opostos, embora estejam em um mesmo contexto, que é a respiração. "Expirar" é soltar o ar que está nos pulmões, enquanto "inspirar" é absorver o ar do exterior. "Inspirar" ainda pode significar "inspiração", que é um lampejo de motivação para uma determinada atitude. Nesse pequeno jogo de significação da palavra, estando ela associada diretamente ao produto na parte final das peças, onde se atinge $o$ repouso e a significação final da criação, está o fator determinante para a ação do público-alvo perante o produto, dando margem para várias interpretações, entre as quais "Arbo inspira".

As fontes tipográficas utilizadas nas peças também exercem papéis importantes na identificação com o público-alvo. As palavras "Expire" e "Inspire" estão escritas em fontes contínuas, todas em letras minúsculas ("caixabaixa"), sem destaques como negrito ou itálico e sem serifa, de maneira tal que a grafia tenha impacto sem desviar a atenção da imagem, com objetividade e concisão.

Dividindo as peças entre a parte "Expire" e a parte "Inspire", podemos identificar vários elementos visuais que objetivam constituir uma identificação com o público-alvo, o produto e o sentido conceitual da criação da campanha publicitária. São três imagens distintas para os elementos urbanos relacionados à "Expire", e duas imagens distintas para as paisagens de natureza relacionadas à "Inspire", além da imagem do produto, sempre buscando o contraste entre os elementos.

A partir de tais elementos, surgem nas imagens signos dos ambientes nos quais se busca situar o público-alvo. Os arranha-céus, no papel dos 


\begin{tabular}{|l|l|}
\hline \multicolumn{1}{|c|}{ “Expire” } & \multicolumn{1}{c|}{ “Inspire” } \\
\hline Elementos Urbanos: & Elementos da Natureza: \\
- Arranha-céus & - Árvores e folhas \\
- Avenida & - Cachoeira e riacho \\
- Carros & - Água \\
- Luzes noturnas & - Pedras \\
- Pessoas em movimento & - Lugares desabitados \\
- Metrô, estação de trem & - Mata \\
- Linhas retas & - Linhas sinuosas \\
- Azul e cinza & - Verde e amarelo \\
\hline
\end{tabular}

grandes edifícios comerciais, a avenida, os carros e as luzes noturnas de postes e veículos em um cenário típico dos congestionamentos de final de tarde, o metrô e as pessoas em movimento, representando o momento de pico pela manhã quando muitas pessoas estão pegando a condução para o trabalho, simbolizam a correria da cidade grande, a busca pelo sucesso profissional e as dificuldades de um mundo competitivo e tenso, demonstradas pelas linhas retas sinalizando rigidez e metodismo. Pelo outro lado, a água parada, a mata em descanso, a cachoeira em queda livre, a sombra das árvores protegendo do sol e o riacho que corre sobre pedras sugerem uma associação à expressão popular "sombra e água fresca": descanso, relaxamento, paz, tranqüilidade, frescor e água abundante, longe do estresse da vida urbana. As linhas sinuosas presentes nas silhuetas das árvores, na água corrente e na cachoeira em queda livre sugerem a liberdade dos movimentos, sejam eles físicos ou de pensamento.

As imagens destes cenários, uma ao lado da outra, associadas às palavras "Expire" e "Inspire", em seqüência, ditam um ritmo na leitura visual e interpretação das mensagens, distanciando e aproximando a conclusão do leitor até o final "Inspire" com o perfume Arbo, em substituição à imagem da natureza - relação que surge, principalmente, pelo meio do uso de cores similares. A criação sustenta o contraste de cores entre as peças com imagens com tons de azul e cinza e detalhes de outras cores, para a palavra "Expire", e o verde, basicamente em sua totalidade, apenas com leves tons pendendo para o amarelo, nas imagens associadas à palavra "Inspire".

De acordo com Goethe (1993, p. 132), cores distintas proporcionam estados de ânimos específicos. Para ele, a cor azul "produz um efeito especial quase indescritível. [...] é uma energia, mas está do lado negativo e, na sua mais alta pureza, é por assim dizer um nada estimulante. Ela pode ser vista como uma contradição entre estímulo e repouso". A cor azul está nas peças associada às fotografias de cenas urbanas, com prédios e carros e pessoas em movimento, também associadas à "Expire". O cinza, juntamente com os tons azulados, de acordo com a teoria da cor, refere-se à "mistura dos pigmentos pretos e brancos" e "é a cor geralmente associada à tristeza e a temas fúnebres" (WIKIPEDIA, 2005). Pode-se julgar a partir disso que a sugestão da ação de expirar seria mais adequada aos ambientes urbanos, dando margem para algumas interpretações, como a existência de poluição nas metrópoles, um fator que seria nocivo ao ato de "Inspirar", ao contrário da natureza, onde o ar seria puro, sem poluição e benéfico à saúde.

Sobre o verde, Goethe (1993, p. 134) diz que "nosso olho tem uma satisfação real com essa cor. [...] o olho e a alma repousam nessa mistura como se fosse algo simples". Ele ainda chamava o ponto de anulação entre oposições de "verde", significando o equílibrio entre as forças, e também dizia que o verde era a cor da esperança.

Os tons brancos da imagem arquitetônica da parte do "Expire" (aconselha-se entrar no site de O Boticário, ou OpusMúltipla, para ver as imagens) estão nos detalhes das nuvens, com o céu, transmitindo magnitude e amplitude. O branco também está presente em uma das imagens da parte "Inspire", na espuma da água da cachoeira, e ali representaria a limpeza, associação suposta de um perfume, que tende a deixar o aroma agradável, característica não peculiar a algo sujo. Em outra imagem com elementos urbanos há o vermelho, que dá um nuance de contraste com o azul, 
trazendo à tona a agitação sugerida pela cor, que deriva da expressão "cor do sangue" que, de acordo com Guimarães (2004), provavelmente derivou de guerras e confrontos de tempos longínquos na história da humanidade.

Nas imagens da parte "Inspire" da campanha destaca-se o verde, cor predominante nas matas e na natureza - inclusive nas águas, em tons azulados. O verde é, culturalmente, um signo, quando se trata de meio-ambiente e ecologia. É também a cor da esperança e do equilíbrio. Dentro do universo da mitologia, segundo Guimarães (2004, p. 115), representado pela deusa VênusAfrodite, é a personificação e o aspecto mais feminino da natureza. Guimarães ainda diz que o verde, ocupando posição central no espectro eletromagnético, está eqüidistante dos seus dois extremos, e sendo então a cor recebida com menor agressividade pela retina, é a que traz mais tranqüilidade ao nosso ânimo. Segundo Kandinsky (1991) apud Guimarães (2004), a passividade é a característica dominante do verde absoluto.

Se, por um lado, a informação cromática contida em um produto de comunicação deve ser recebida da forma menos ambígua possível, ou seja, deve haver a correspondência entre o conteúdo produzido e o repertório de leitura, de outro, será de responsabilidade do produtor da informação conhecer e aplicar o repertório a ser compartilhado e, do pesquisador, encontrar as estruturas mais profundas em que aquela informação foi construída (GUIMARÃES, 2004, p. 107).

Por essas razões, a utilização do verde no ramo de cosméticos e perfumaria é constante, sendo que a própria empresa $\mathrm{O}$ Boticário faz uso do verde em sua logomarca. As diferenças nas tonalidades de verde das imagens em questão ainda geram variações de amarelo e o azulado das águas. Verde e amarelo (e também o azul, em menor proporção), culturalmente, são signos do Brasil, como bandeira e como pátria. Atinge-se uma identificação com o público-alvo: as brasileiras.

A fotografia é a base da produção das imagens utilizadas na campanha. Por meio da escolha dos ângulos e de algumas técnicas na captura das imagens, algumas observações podem ser feitas sobre o estímulo visual que elas causam.

Percebe-se inicialmente que todas as fotografias possuem o enquadramento ou corte vertical, em uma proporção próxima a 2:3, que possibilita uma melhor adequação das peças às páginas de revistas.

Na imagem dos edifícios da peça sêxtuplo no 1 , o plano de enquadramento é conhecido como contra-plongée, de baixo para cima, comum na fotografia de arquitetura. Segundo Patrício (1999, p. 80), "dando idéia de poder". Ao lado, a imagem é de uma paisagem ao redor de uma cachoeira, em um plano geral, que mostra praticamente tudo no cenário.

A peça sêxtuplo $\mathrm{n}^{\mathrm{o}} 2$ traz a imagem de uma avenida com tráfego pesado e também ao lado de uma paisagem da natureza. A imagem da avenida, com os carros, foi feita com uma técnica que explora a baixa velocidade do obturador da câmera fotográfica, deixando tudo que está movimento com um aspecto de borrado, conseqüentemente transmitindo a sensação de movimento ao receptor visual da mensagem. Esta imagem também não deixa de ser uma paisagem, pois exibe não somente os carros como todo o ambiente que os cerca, assim como na fotografia ao seu lado na mesma peça, onde o enquadramento foi feito de forma a explorar o efeito de espelhado proporcionado pelo reflexo das árvores na água, sugerindo um mundo imaginário.

$\mathrm{Na}$ peça sêxtuplo $\mathrm{n}^{\mathrm{o}} 3$, em um plano similar ao da peça anterior, em vez de uma avenida, existe uma passagem de pessoas, em um metrô ou estação de trem e, em vez de carros em movimento, são pessoas em movimento. A técnica usada na fotografia para a transmissão dessa sensação de movimento foi a mesma da baixa velocidade do obturador. As pessoas, borradas, perdem a identidade, mas não a significação pertinente às suas silhuetas, elemento que se deseja mostrar realmente. A fotografia final das peças é a do produto em si, quebrando o ritmo estabelecido. É uma fotografia feita em estúdio, fugindo do padrão das anteriores, iluminado artificialmente com técnicas que buscam enaltecer o design do produto.

A embalagem do produto, no que diz respeito ao seu design, parte da silhueta de uma folha, a tampa numa tonalidade de verde claro e o corpo do frasco em outra. Ao fundo, predominantemente branco (sugerindo limpeza), estão alguns desenhos de folhas, em verde muito claro para que o branco não perca sua significação: feminilidade e limpeza. A fonte utilizada na palavra "Arbo" lembra uma grafia feita com gravetos, ou ranhuras em uma casca de árvore, criando 
juntamente com as cores e o formato do frasco do produto uma associação direta com o elemento natureza. A cadência no ritmo seqüencial das peças não se altera com um impacto visual brusco, mas sim em uma resolução harmoniosa.

A Parte I de A fenomenologia da percepção, de Merleau-Ponty (1971) apud Cobra (2005), discorre com grandes detalhes sobre o papel do corpo e da imagem corporal, com abundantes referências a descobertas empíricas nesses assuntos. Há um capítulo sobre sexualidade e o capítulo final trata da expressão corporal e, mais importante ainda, da fala. A Parte II desenvolve e transforma tudo isso em uma teoria geral de percepção, envolvendo espaço, coisas e outras pessoas. O papel do corpo torna-se supremo em tudo isso porque é ele e seus movimentos que proporcionam a "concretização" de nosso conceito de espaço e, dessa maneira, dos objetos que nele estão.

\section{Considerações finais}

Como conclusão, este trabalho traz à tona, por meio da leitura dos elementos visuais e da fundamentação teórica, a exploração de possibilidades criativas na área da Publicidade \& Propaganda para que determinados produtos sejam enaltecidos sem uma explícita mostra de suas características, como no caso o aroma da fragrância Arbo. Em relação ao objetivo geral da pesquisa, conclui-se que o estímulo da ação de compra de um perfume, sem que se perceba realmente o seu aroma, pode ser feita por meio de signos que remetam o público-alvo a situações nas quais experiências passadas possam trazer para o presente fatos que coincidem com o que está sendo mostrado, e o estímulo do inconsciente e da memória, direcionado ou não para um sentido em particular, como o olfato, pode ser feito por meio de outros sentidos, como a visão, neste caso específico da campanha "Expire e Inspire".

Ao objetivo específico de se compreender a carga de responsabilidade da aplicação das cores nas imagens, pode-se dizer que foi um fator determinante. A cor é uma característica fundamental na percepção visual do homem e contém um enorme poder de carregar consigo informações culturais. A cultura de cada públicoalvo específico tem sido objeto constante de estudo na área de comportamento do consumidor. Quanto ao objetivo de analisar as possibilidades da transmissão de sensações, como o som e o movimento por meio de imagens estáticas, concluise que, com determinadas técnicas, seja em uma fotografia ou em um desenho ou ilustração, a possibilidade não só existe como também a mensagem pode ser transmitida com clareza e objetividade, se estas técnicas forem bem executadas.

Como sugestão para estudos futuros, fica a descoberta de que existe a possibilidade de que uma criação publicitária bem desenvolvida possa também estimular o Equilíbrio que, se ainda não pode ser chamado de sentido, como o olfato, a visão, o tato, o paladar e a audição, ao menos já está sendo considerado uma forma de percepção, sendo, portanto, mais uma maneira de se transmitir sensações, pela comunicação.

\section{Referências}

\section{8ํㅡㄹ PRIO Colunistas do Paraná. Ata da premiação. Disponível em: <http://} Ww w . colunistas. com/propaganda/ prpr28ata2004.html>. Acesso em: 11 nov. 2005.

AZEDO, Sandra. Cosmética dispara com salto de qualidade. Disponível em: <http:// www.unicamp.br/unicamp/canal_aberto/clipping/ junho2004/clipping040602_gazetamercantil.html>. Acesso em: 30 out. 2005.

BARTHES, Roland. Elementos de semiologia. Tradução Isidoro Beikstein. São Paulo: Cultrix, 1979.

COBRA, Rubem Q. Fenomenologia. Filotemas. Brasília, 2001. Disponível em: $<$ www.cobra.pages.nom.br>. Acesso em: 20 jun. 2005 .

ECO, Umberto. Tratado geral de semiótica. Tradução de Antônio de Pádua Danesi e Gílson César Cardoso de Souza. São Paulo: Perspectiva, 1980.

FANTÁSTICO. [homepage na Internet]. Disponível em: <http://www.globo.com/fantastico>. Acesso em: set. 2005 .

GOETHE, J. W. Doutrina das cores: apresentação, seleção e tradução de Marco Giannotti. São Paulo: Nova Alexandria, 1993. 
O estímulo dos sentidos através das imagens: estudo de caso

GUIMARÃES, Luciano. A cor como informação: a construção biofísica, lingüística e cultural da simbologia das cores. São Paulo: Annablume, 2004.

MARTINS, Zeca. Propaganda é isso aí!: um guia para novos anunciantes e futuros publicitários. São Paulo: Atlas, 2004.

NINIO, Jacques. A impregnação dos sentidos. Tradução de Ana Cristina Neto. Lisboas: Instituto Piaget, 1991.

NORMAN, Richard B. Electronic color: The Art of Color Applied to Graphic Computing. Disponível em: <courses/cs092/VA10/HTML/ GoethesTriangleExplanation.html" http:// www.cs.brown.edu/ courses/cs092/VA10/HTML/ GoethesTriangleExplanation.html>. Acesso em: 27 out. 2005.

O BOTICÁRIO. Arbo feminino $\mathbf{1 0 0} \mathbf{~ m l}$. Disponível em: <http://www.boticario.com.br/portal/site/ produtos/mulheres_perfumes_07921.asp $>$. Acesso em: 29 out. 2005.

OPusmúltipla, Campanha desenvolvida mostra a essência do Arbo feminino. Disponível em: <http://www.opusmultipla.com.br/ sitenovo/ noticias_main.asp? idNoticia $=54>$. Acesso em: 29 out. 2005.

PATRÍCIO, Djalma. Curso básico de fotografia. Blumenau: Edifurb, 1999.

PEIRCE, Charles S. Semiótica. Tradução de José Teixeira Coelho Neto. São Paulo: Nova Perspectiva, 1977.

PÉNINOU, G. et al. A análise das imagens. Petrópolis, RJ: Vozes, 1973.
PRÊMIO Abril de Publicidade. Hall of fame. Disponível em: <http:// www.premioabrildepublicidade.com.br/hall/ halloffame_2005_sul.asp>. Acesso em: 11 nov. 2005.

SAMPAIO, Rafael. Propaganda de Aa Z: como usar a propaganda para construir marcas e empresas de sucesso. Rio de Janeiro: Campus, 2003.

SANTAELLA, Lúcia. O que é semiótica? São Paulo: Brasiliense. 1990.

VERONEZZI, José Carlos. Mídia de A a Z: os termos de mídia, seus conceitos, critérios e fórmulas, explicados e mostrados graficamente como são utilizados na mídia. São Paulo: Edicon, 2002.

WIKIPEDIA. Wikipedia, a enciclopédia livre: cinza. Disponível em: <http://pt.wikipedia.org/ wiki/Cinza>. Acesso em: 08 nov. 2005.

\section{Bibliografia complementar}

METZ, Christian et al. A análise das imagens: seleção de ensaios da revista Communications. Tradução de Luís Costa Lima e Priscila Vianna de Siqueira. Petrópolis: Vozes, 1973.

PATRÍCIO, Djalma. Editoração gráfica: aprenda fácil. Blumenau: Edifurb, 2005.

SANTAELLA, Lúcia. NÖTH, Wilfried. Imagem: cognição, semiótica e mídia. São Paulo: Iluminuras, 1998.

SIEVERT, Marilde. Texto publicitário: dicas não são receitas. Blumenau: Edifurb, 2001.

Recebido: 04/12/2006 Aceito: 07/02/2007 